\title{
A Study of Chi-Chen Wang's Translation Strategies of Modern Chinese Literature
}

\author{
Saisai Huang ${ }^{1}$ \\ ${ }^{1}$ Foreign Languages Department, Zhejiang University of Finance and Economics, Dongfang College, Haining, \\ China \\ Correspondence: Saisai Huang, No.2 Yangshan Road, Haining, Jiaxing City, Zhejiang Province, China. E-mail: \\ strawberrysaisai@163.com
}

Received: August 31, 2018 Accepted: September 20, 2018 Online Published: January 24, 2019

doi:10.5539/ells.v9n1p45 URL: https://doi.org/10.5539/ells.v9n1p45

\begin{abstract}
Chi-Chen Wang (1899-2001) is a trailblazer in promoting Chinese literature in the West and is also one of the earliest scholars who made modern Chinese literature known to the Westerners. As a both renowned writer and translator in the West, Chi-Chen Wang's translation motivation, his comment on modern Chinese literature together with the social background of his translation activities has a great influence on his choice of translation strategies. The study provides a detailed discussion on Wang's choice of translation strategies by analyzing his translation motivation, the cultural and political climate of his translation activities as well as his own literary judgments. And the textual analysis of his translation reveals that Wang' translations incline to retain the foreignness in the source text and revise the original texts through condensation and deletion.
\end{abstract}

Keywords: Chi-Chen Wang, translation strategies, foreignness, condensation and deletion, modern Chinese literature

\section{Introduction}

Translation is now considered more than a linguistic trans-coding between the source and target languages but rather a cross-cultural activity taken place in the broader historical and social frame. In translation practice, translators' motivation, value, and cultural orientation could make a great difference on the strategies they choose to fulfill their tasks, thus influencing the function and the reception of the translation in the target culture. Therefore, how and to what degree the translator's cultural and political orientations or aesthetic tendencies have influenced his choice of translation strategies has become a new dimension in translation research.

Chinese literature began to enjoy an increasing Western readership around the mid-20th century, and Chi-Chen Wang (1899-2001), an academically active translator, produced a considerable amount of excellent translations at that time. He made his translation debut in the U.S. with his translation of Dream of the Red Chamber in 1929 and was thereafter known as the first Chinese who translated this great classical novel into English. Most significantly, he translated many short stories of modern Chinese writers such as Lu Xun, Lao She, Ba Jin, Shen Congwen, Zhang Tianyi, Mao Dun, Ye Shaojun and so on, which were published in his Contemporary Chinese Stories (1944). As one of the earliest scholars who made modern Chinese literature known to Americans, Wang contribute to projecting the true image of China in the West. In view of the political and cultural settings against which Wang did most of his translation and his own cultural identity, this study attempts to provide a panoramic view of Wang's translation strategies in translating modern Chinese literature.

\section{An Overview of Translation Strategies}

Discussion on translation strategies can be traced back to the German philosopher and theologian Friedrich Schleiermacher who argued that 'there are only two. Either the translator leaves the author in peace, as much as possible, and moves the reader toward him. Or he leaves the reader in peace, as much as possible, and moves the author towards him.' (qtd. in Lefevere, 1992a, p. 149) It is expected that the translator should be either on one side or the other. This binary division also finds expression in the definition given in Routledge Encyclopedia of Translation Studies (Venuti, 2009, p. 240) which goes further to divide translation strategies into two large categories - domestication and foreignization. The former "may conform to values currently dominating the target-language culture, taking a conservative and openly assimilationist approach to the foreign text", while the 
latter "may resist and aim to revise the dominant by drawing on the marginal, restoring foreign texts excluded by domestic canons" (ibid). Toury (2001, p. 56) also expressed a similar opinion when he expounded on the idea of the initial norm. He regards translation as a norm-governed activity that will inevitably involve at least two cultures and two cultural traditions. According to Toury (ibid), a translator will be first confronted with the initial norm, which is constituted by the basic choice made between requirements of the two different sources, thus the translator "may subject him-/herself either to the original text, with the norms it has realized, or to the norms active in the target culture".

Since translation involves cultural communication and conflicts, the traditional binarism prescribes that the translator should be either on the side of source culture or the target culture. However, when translation research operates with those mutually exclusive terms, as Hermans (2004, p.119) put, "it remains blind to all those ambivalent, hybrid, unstable, mobile, overlapping and collapsed elements that escape binary classification". For this reason, Chesterman $(1997$, p. 88$)$ tends to consider translation as an action, to place it in the wider context of action theory, and thus "strategy is a kind of process, a way of doing things". According to Chesterman, strategies describe types of text-linguistic behavior and are operations of a translator resulting from the desired relation between the target text and the source text, which in turn is "determined by other factors, such as the intended relation with the prospective readers, social and ideological factors etc."

Therefore, it can be concluded that translation strategies adopted by a translator are results of his negotiation of the conflicts between the source and the target cultures, which ultimately depend on his own attitude towards the source culture and the receptor culture, not inconsequentially the desired function of the translation as well as the prospective readership. Thus, the translation strategies discussed in this study focus on Wang's selection of strategies motivated by the cultural and political climate of translation and the target readers' expectations in the sense of global strategy, and his methods or ways in processing the translation based on his own cultural and literary judgments in the sense of local strategy.

\section{Factors Influencing Wang's Choice of Translation Strategies}

\subsection{Historical Background of Wang's Translation}

As Lefevere (1992b) regards translation as rewriting under the manipulation of "ideology and poetics", the practice of translation as a cross-cultural activity cannot escape the influence of ideology, which exerts an impact on the translator's choice of a certain translation task as well as the methods to fulfill the task. The time from 1920s to 1940s when Wang carried out most of his modern Chinese literature translation is a period when the Sino-American relation underwent a deep change that witnessed America's showing of sympathy and friendliness to China. American journalist and political scientist Isaacs (1958, p. 86) described this period as the age of benevolence (1905-1937) and the age of admiration (1937-1944). At the turn of the 20th century, the United States entered world politics as a principal player and, the Open-Door policy became a pillar of a new American diplomacy. The revolutionary China with its new nationalist forces unknown before attracted America's attention. Fueled by various political, economic, and religious interests, America viewed China as a country ripe for Americanization and Christianity, a country in need of its guidance and help. And in the 1930's and 1940's, the prevalent American view of China was that of a friendly, democratic, and increasingly Christian state. This view was fostered by political, business, and literary leaders, including Franklin D. Roosevelt, Henry R. Luce, the powerful publisher of the magazines Life and Time, and most notably, Pearl S. Buck. Besides, other writings about China such as Edgar Snow's Living China and works by Chinese writer Lin Yutang gave the Americans a glimpse of this land filled with life, hope and wisdom. These images, either through events, books, or pervading social climate, were widely spread and absorbed and became part of the mental baggage of most Americans. Thus, publications about China in the early 1920s to 1940s were gaining popularity in the market. And it was no coincidence that Wang did most of his translations during this period. And the political and cultural background provided a good opportunity for the introduction of modern Chinese literature into America (Li \& Zhu, 2018, p.84). Venuti (2009, p.240) proposes that strategies of translation should first involve the basic task of choosing what to be translated and then develop a method to translate it. During this period, Wang's translation of modern Chinese literature is mostly concerned about modern Chinese fictions produced in different time-periods, with his anthology Contemporary Chinese Stories covering the period from 1918 when the Literary Revolution began in earnest to 1937 when the Sino-Japanese War broke out, and his collection Stories of China at War dealing with Chinese war-time short stories written from 1937 to 1942. Most of these translations provided the updated image of China to the West, including short fictions reflecting Chinese social and cultural conflictions in the modern age and wartime stories showing the heroic deeds and spiritual supports of the most Chinese people during anti-Japanese war. 


\subsection{Wang's Comments on Modern Chinese Literature}

Wang's literature preferences also influenced his selection of translation strategies. Although the translator is heavily influenced by ideology, he is not absolutely controlled by it, and his own cultural values are also involved in making translation decisions. Wu Bo (2006, p.128) holds that the translator makes his or her personal decisions while choosing translation strategies based on how he or she understands the source and the target cultures and the translation situation. And in most cases, the translator "endeavors to protect the values s/he holds in esteem", and "the translator's selection of translation strategies reveals his/her fundamental cultural orientation" (ibid, p.129). As a result, it stands to reason that the translator's cultural attitude and cultural identification play a significant role in his or her employment of specific translation strategies.

Wang (1934, p.127) gave a detailed account on the development of modern Chinese literature and held that modern Chinese literature was a "direct outcome of the impact of the West". Thus, he appreciated the efforts of the leaders of the literary revolution who succeeded in introducing the Western notions of what the ideals of literature should be into China and advocated the Western influence on modern Chinese literature since the beginning of the $20^{\text {th }}$ century. He believed that a great deal remained to be done as to improving the writing techniques and language of most modern works, as one can take a glance of his comments from the attached notes on the authors in his collection of Contemporary Chinese Stories (1944).The works in Contemporary Chinese Stories are attributed to modern Chinese writers such as Zhang Tianyi, Lao Xiang, Lao She, Ba Jin, Shen Congwen, Feng Wenbing, Ling Shuhua, Mao Dun, Ye Shengtao, Lu Xun, and Yang Zhensheng. While choosing these writings to translate, he considered the technical excellence of stories, the position occupied by the author and the light the story throws on Chinese life and problems. (Wang, 1944, p. viii) And Wang did not find all these works impeccable. For example, Wang (ibid, p. 240) argued that Shen Congwen drew much from his nostalgia for his personal past which always gave his stories an idyllic coloring, yet he was always under the necessity of writing to make a living during his most active years, and thus most of his books suffered from haste and padding. Additionally, Wang did not think highly of the productions of Mao Dun despite his great reputation by saying that although he was familiar with the methods and devices of Western literature, "he had made use only of such obvious tricks as the flash-back and nightmarish glimpses into the future which the movies have exploited ad nauseam" (ibid, p. 241). He concluded that before Chinese literature could astound the world, it must acquire the spirit and methods that made possible the achievement of the West. (Wang, 1946, p. 396) So, modern Chinese literature was deemed as a product of exchanging with foreign literature and conforming to a Western mode of writing. By comparing Wang's translation of modern Chinese stories with their original versions, one can perceive that this value judgment controls his translation strategies and makes him incline to revise the original texts to conform to the Western literary mode.

\section{A Textual Analysis on Wang's Translation Strategies}

\subsection{Condensation and Deletion}

Drawing on the above discussions on the historical background of Wang's translation practice as well as his literary thoughts and values, it can be concluded that the process of Wang's translation is primarily governed by his knowledge of the prospective readership and his own literary judgments. For a deeper understanding of how these factors affect his choice of translation strategies, the following part will be a textual analysis on Wang's translation strategies. One can easily find that the translator condenses and deletes sentences or even paragraphs when necessary or changes the original plot arrangement. Below are some examples from Wang's translation of modern Chinese fictions.

Yujun is a modern Chinese novella written by Yang Zhensheng in the 1920s. As the longest of the new fiction ever attempted at the time of its publication, it has attracted wide attention among both the old and new literature circles in China. The story touches on the most dealt with topic of female independence as well as the intellectual's perplexity towards society, tradition and love. The hero Lin Yicun was asked to take care of Yujun, the lover of his friend Du Pingfu before he went to study abroad, whose relationship aroused fierce opposition among the girl's family because of their family feud. However, Lin Yicun used to have a crush on Yujun in his adolescence and still cherished a secret love for her though he never expressed his love out of his respect for his friend. Yujun managed to survive a suicide with the help of Lin Yicun after his father pushed her to marry a general's son. When Du Pingfu was back, he mistakenly believed that Lin Yicun and Yujun had fallen in love, which hurt Yujun but also contributed to her awakening. Later, Yujun managed to study abroad because of Lin's unconditional love and devotion. Although the story is written in vernacular Chinese, it is still encumbered with homilies and redundant depictions characterized by traditional Chinese fiction. The original writing consists of 19 chapters, but Wang retains only 10 chapters in his translation. To highlight the main plot and Lin's love for 
Yujun, Wang deletes the subplots of the love between Lin's servants Xing'er and Qin'er as well as the depiction of Lin and Yujun's sightseeing on an island where they decided to build a school for the local girls. Other episodes like Lin falling ill and dreaming absurd dreams, the detailed description of Lin's fishing experience and Lin's affection for Yujun's younger sister Lingjun are all deleted. What's more, Wang also cuts out most of Lin's monologues and his lengthy remarks on reforming social institutions or advocating gender equality and sharp denunciation of neo-Confucianism. It is noticeable that the original text preserves many writing techniques of traditional Chinese novels like verbose narrative on minor details and cumbersome preaching from the hero. As for the writing skills, Wang holds that Yujun is only recommendable as a long story or at most a novelette compared with those of Mao Dun and Pa Jin who have attained a high degree of technical proficiency. In his translation he makes some revisions to the story as he confesses, "I have omitted altogether some sections that have nothing to do with the main story and have summarized some of the more than ordinarily perfunctory descriptions and dialogues." (Wang, 1944, p. 242)

The original novel tends to have overly detailed description of the characters' bearings and behaviors. But Wang tries to condense it into a few sentences. The underlined sentences in the source text are deleted in Wang's translation.

1. 玉君乍见时红了脸, 慢慢地向前踱。海风吹得她的玉白纺绸刺花短袖褂子与下身哔吹百禇白裙都翩翩 向后飞舞, 像阻止她的前进。她的柔黑的眼珠, 满含着差涩的笑意道: “林先生, 你可记得十几年前的玉 君?”(Liu, 1999, p. 18)

"Mr.Lin, do you remember Yujun after all these years?" She walked up slowly and said to me, smiling and blushing a little. (Wang, 1944, p. 200)

2. 我嗫嚅地走进去, 见玉君坐在一张靠壁的软椅上。见我进来, 她站起来, 脸上发阵微红差怯怯地向我 道了谢。她不十分站得住，不等让我坐下，便懒倦地先坐下去。我在背窗的一张椅子上坐了。我见她面 上虽甚沉静, 但是犹带忧思, 颇有疑虑不安的样子。她觉出我的注意, 便微差地低下头去, 不好意思发 言。(Liu, 1999, p. 46)

Yujun was sitting in an easy chair when I went into her room. She was outwardly calm, but she could not entirely conceal her anxiety and embarrassment. (Wang, 1944, p. 217)

3. 菱君听罢, 两手捧些石子跑了过来, 只见她雪白的皮肤, 乌黑的头发, 星目朱愿, 犹是当年玉君的样 子。我同她握手, 她把石子用左手向胸前捧着, 抬起右手来与我握手。（Liu, 1999, p. 19）

Lingjun came running over and transferred all her pebbles to her left hand and held them against her breast so that she could shake hands with me. (Wang, 1944, p. 200)

Besides, since Yang Zhensheng has a good command of classical Chinese poetry and lyrics, he gives it the fullest play in the novel. He adds many depictions of visual imagery adapted from traditional Chinese poetry, which permeates the novel with rich classical flavor. The beauty of the word received high acclaim from advocates for old literature in China. But this excessive use of poetic image is considered to be perfunctory and unnecessary by Wang. In the following cases, the underlined part is all deleted in the translation.

4. “蒙蒙细雨在海上打起千万个白波, 湿淋淋沉重的载客小舟就靠拢到轮船边, 在人声噪杂中脚夫挣扎着 拉下了我的行李, 把我一块儿用小舟渡到海岸上...从雨丝迷离中, 望见了城郭, 又望见了家里的几株老 柳树。”(Liu, 1999, p. 28)

The translation was condensed into one sentence, "A few days later I was back in my native city in a drizzling rain." (Wang, 1944, p. 206)

5. 及到我们回到园子里, 树影在墙, 落日啣山, 对对的鹊鸦已都向巢儿飞归。(Liu, 1999, p. 81)

The sun was just over the hills when we returned to the orchard. (Wang, 1944, p. 224)

As to the writing of more renowned writer such as Lao She, whose works account for a large part in his translation, Wang commends that Lao She will be better remembered for his short stories rather than his novels. There are six short stories of Lao She in Contemporary Chinese Stories and Stories of China at War, namely, “Black Li and White Li” (《黑白李》), “The Glasses" (《眼镜》), “Grandma Takes Charge” (《抱孙》), “The Philanthropist” (《善人》), “Liu’s Court” (《柳家大院》), “The Letter from Home” (《一封家信》). And among them "The Glasses", "Liu's Court" and "The Letter from Home" go through some deletion and condensation.

"The Letter from Home" is collected in Stories of China at War, a translation collection of war literature in China written from 1937 to 1942, a period when "there was an air of hopefulness in the land which infected the masses and the intellectuals alike" (Wang, 1947, p. v). And the early years of the war saw the greatest literary productivity with writers professing aims of reaching the masses. "The Letter from Home" was written in 1939 
when Lao She plunged himself into writing for the anti-Japanese war. The hero Lao Fan in the story, after struggling time and again in the dilemma of "home" and "country", finally left home and fought for the freedom of his country despite his longing for his child and thoughtless wife. In the end, while reading a letter fraught with complaints from his wife, he was killed by a bomb blast. "Since the eruption of the anti-Japanese war, Lao She had been committed to finding a compromise between 'home' and 'country' out of his pragmatic attitude towards culture and traditional Chinese way of thinking" (Zhang, 1991, pp. 91-92); therefore, there is a great deal of depiction of the hero's indecision whether to leave home or not. However, about one seventh of the original text of "The Letter from Home" is deleted. Apart from the usual repetitive and longwinded narration, in most cases, Wang also deletes the lengthy psychological description of the hero and the redundant words that seem to slow down the development of the main plot of a short story to achieve wit, concise characterization and clever twist endings which the Western readers are most familiar with.

1. 况且, 她还生了小珠。在生了小珠以后, 她显着更圆润, 更开通, 更活泼, 既是少妇, 又是母亲, 青 春的娇美与母亲的尊严联在一身, 香粉味与乳香合在一处; 他应当低头! 不错, 她也更厉害了, 可是他 细细一想呢，也就难以怪她。女子总是女子，他想，既要女子，就须把自己放弃了。再说，他还有小珠 呢, 可以一块儿玩, 一块儿睡; 教青年的妈妈吵闹吧，他会和一个新生命最亲密的玩要，作个理想的父 亲。他会用两个男子一一他与小珠一一的嘻笑亲热抵抗一个女性的霸道; 就是抵抗与霸道这样的字眼也 还是偶一想到, 并不永远在他心中, 使他的心里坚硬起来。(Lao She, 1982, p. 342)

Moreover, she was a mother, combining in her person the beauty of youth and of motherhood. He ought to be more considerate of her, yield to her whims and moods even more. After all, women are women. If one wants a woman, one just has to make allowance. (Wang, 1947, p. 128)

2. 乘小珠和彩珠睡熟, 老范轻轻的到外间屋去。把电灯用块黑布罩上, 找出信纸来。他必须逃出亡城, 可是自结婚以后, 他没有一点儿储蓄, 无法把家眷带走。即使勉强的带了出去, 他并没有马上找到事情 的把握, 还不如把目下所能凑到的一点钱留给彩珠, 而自己单独去碰运气; 找到相当的工作, 再设法接 她们; 一时找不到工作, 他自己怎样都好将就活着, 而她们不至马上受罪。好, 他想给彩珠留下几个字, 说明这个意思, 而后他偷偷的跑出去, 连被裖也无须拿。他开始写信。心中像有千言万语, 夫妻的爱恋, 国事的危急，家庭的责任，国民的义务，离别的难堪，将来的希望，对妻的安慰，对小珠的嘱托......都 应当写进去。可是, 笔画在纸上, 他的热情都被难过打碎, 写出的只是几个最平凡无力的字！撕了一张, 第二张一点也不比第一张强, 又被扯碎。他没有再拿笔的勇气。一张字纸也不留, 就这么偷偷走? 他又 没有这个狠心。他的妻, 他的子, 不能在国危城陷的时候抛下不管, 即使自己的逃亡是为了国家。(Lao She, 1982, pp. 344-345)

One evening, after Tsai-chu and Hsiao-chu had gone to sleep, Fan slipped into the outer room. He put a piece of black cloth over the electric light and got out some letter paper. He would write her a note explaining why he must flee from the lost city, why it was better that he go alone first and send for her and Hsiao-chu after he had found a position. He made several starts but in the end gave up the attempt. (Wang, 1947, p. 130)

3. 紧急警报! 他立在门外, 拿着那封信。飞机到了, 高射炮响了, 他不动。紧紧的握着那封信, 他看到 的不是天上的飞机, 而是彩珠的飞机式的头发。他愿将唇放在那曲折香润的发上; 看了看手中的信纸; 心中象刀刺了一下。(Lao She, 1982, p. 348)

As the siren wailed its final warning Fan was still standing outside his building, still holding and staring at the letter. (Wang, 1947, p. 132)

While giving due compliment on Lao She's faithful transcribing of Beijing dialect, Wang makes the translation both easier and more engrossing for the target readers by conforming his translation to the Western literature mode. And the adoption of deletion and condensation makes his work more an adaption than a translation.

\subsection{Retention of the Foreignness}

Every language with its culture-bound terms mirrors the unique life styles, customs, and mode of thinking of its speakers. And it is usually hard to find the exact corresponding words in another language; thus, the way a translator handles these words can cast a light on his selection of translation strategies. Wang chose to retain most of the Chinese elements in his translation and took care to retain most of the Chinese elements to cater to the readers' expectation. Readers can easily run into phrases, clichés, expressions and sayings loaded with Chinese flavors, which add to the exoticism of his translation.

For example, words like "k'ang" (bed built of bricks in northern China), "kaoliang" (a powerful alcohol distilled from a grain), "wowotou" (staple article of food in northern China), "kan-ts'ai" (dried vegetable) are all transliterations of the original Chinese expressions. And in most cases, readers have no difficulty in understanding these words based on context. 
(1)可是讲吃, 也是讲外国的。上边光景没有棒子面窝窝, 也没有小葱儿拌豆腐。(Shu, 1999, p. 99)

“And it is always about foreign food. There doesn't seem to be any corn wowotou or bean curd with onions in it." (Wang, 1944, p. 23)

(2) “热的包子咧！刚出屉的 地坐着。(Kong, 2007, p. 193)

"Hot bautze-a-a!" Just out of the steamer..." On an old and rickety table at his side there was a pile of twenty or thirty cold stuffed rolls with not the least suggestion of being hot. (Wang, 1944, p. 190)

In example (1), readers can guess that "wowotou" is a type of Chinese food according to the context. And in example (2), readers can get a clue on the meaning of "bautze" according to the suggestion of "steamer", and Wang translates it into "stuffed rolls" in the following sentence to explain what "bautze" is. As is illustrated by the above examples, transliteration adds foreign ambience to the target text.

Another example is Wang's translation of forms of address. Forms of address deal with people's genetic connection, professions, and especially social positions. They are culture-specific in the sense that they can denote social status, express personal affection and family ties in a cultural community. Since the Chinese language is renowned for its overelaborate and notoriously complex forms of address, which differ greatly from those in English, it lies with the translator to choose his methods of interpretation. In Wang's translation, foreign readers come across words with unique Chinese flavor like Didi (younger brother), Koko (elder brother), Lao-yeh (Your Honor), Ma (a woman servant), Meimei (younger sister), Niang (honorific suffix for women), Saosao (elder sister-in-law), Taitai (mistress in thcwe house). As the meanings of these words and terms are in most cases self-evident, they would not interrupt the readers' reading process. And Wang explained his motivation in adopting this way of translation by saying: "In some of the stories I have found it necessary to introduce a number of Chinese words and honorifics in order to make the dialogues faithful to Chinese conversations." (Wang, 1944, p. viii). Therefore, this way of translation sets the readers in a background with characters talking in the Chinese way and enhances the sense of foreignness of the story.

(3)“我不是提了您好几遍买鞋面, 那知您一出门就忘了, 没鞋面怎么做鞋? ”蔡妈冷笑的答。(Ling, 2002, p. 214)

"But how can you make shoes without the uppers?" Tsai-ma said with a cold smile. "I have reminded Tai-tai to buy some material for the uppers but Taitai always forgets." (Wang, 1944, p. 135)

(4)“大哥, 你当真要把嫂嫂送出去? ”...

“大哥, 三弟的话很对, ”觉民接着说, “我劝你不要就把嫂嫂搬出去...。”(Ba, 2002, pp. 278-279)

"Da-ko are you really going to send saosao away?"....

"Da-ko, San-di is right," Chueh-min said. "You should not give up without a struggle..." (Wang, 1944, pp. 83-84)

Example (3) involves the use of Chinese honorifics developed according to class consciousness and Confucian principles of order and respect in Ancient China. In the original context, Tsai-ma, the maidservant, would address her mistress by the honorific second-person pronoun “您”. It was a proper way for Wang to replace the honorific form with "Taitai" in his translation, which retained the respect carried in the original Chinese. In example (4), Wang preserves most of the numerals of family members in the Chinese conversation, such as "Da-ko" (the oldest brother), "San-di" (third younger brother), and "San-shu" (the third oldest Uncle). And he also attached a glossary to explain those exotic words in case that foreign readers may feel perplexed.

In addition, Wang's translation of Chinese common sayings also reflects his strategy of retaining the foreign elements. Many of the common sayings in Chinese, including proverbs, slangs and set phrases, originate from a wide variety of sources - folklore, history, mythology, old customs and practices, religion and superstition. They are practical and homely terms that reflect the Chinese way of thinking and behavior. In most cases, Wang chose to translate them literally. The following is a list of Wang's translation of Chinese common sayings in "Cloud Over Luchen” (《风波》) by Lu Xun.

(5)“你这死尸怎么这时候才回来, 死到那里去了! 不管人家等着你开饭! ”(Lu, 2013, p. 32)

A fine time for you to be coming home, you dead corpse! Where did you hide off to die? You never care how long people hold up dinner for you, do you?" (Wang, 1941, p. 67)

(6)他偏要死进城去, 滚进城去, 进城便被人剪去了辫子。(Lu, 2013, p. 34)

But he insisted on going into the city—on rolling into the city—and when he got there they got hold of him and 
cut off his queue. (Wang, 1941, p. 72)

Wang's strategy of translating Chinese common sayings is that the translation should be faithful to the original on one hand but not making readers perplexed on the other. In example (5), “你这死尸怎么这时候才回来, 死到 哪里去了! ” was translated into "A fine time for you to be coming home, you dead corpse! Where did you hide off to die", in which the wife refers her husband as "dead corpse" and asks him "Where did you hide off to die". And Wang translates literally the phrase “滚进城去”, a particularly Chinese way of expressing anger and dissatisfaction to the interlocutor, into "rolling into the city", which might fail to convey the speaker's emotion since the English word "roll" does not carry this connotation. In this case, Wang explains in the footnote, saying that "to describe someone as 'rolling' like an egg, particularly a turtle's egg, or to tell him to 'roll away,' is very uncomplimentary" (Wang, 1941, p. 72).

To conclude, Wang is known to translate these culture specific terms in a direct and literal way, which is also supported by many corpus-based researches on Wang's translations in recent years (Yang, 2018, pp. 63-68). By doing so, Wang displayed the foreignness of the source culture to readers of the target culture, thus meeting the expectation of most readers.

\section{Conclusion}

Drawing on the historical background of Wang's translation practice as well as his literary thoughts and judgements, it can be concluded that Wang's translation strategies lie in revising the modern Chinese literature according to his literary judgment on one hand and retaining the foreignness of the original writing to introduce Chinese culture and meet the readers' expectations on the other. His translation process is primarily governed by his knowledge of the prospective readership and his own literary judgments. Although his work may not be so inclusive as to offer a panoramic view of Chinese literature, Wang was a studious and prolific translator who worked hard to build bridges linking the West and the East.

\section{References}

Ba Jin. (2002). Selected Works of Bajin's Classics (pp. 278-279). Beijing: The Contemporary World Press.

Chesterman, A. (1997). Memes of Translation: The Spread of Ideas in Translation Theory (p. 88). Amsterdam/Philadelphia: John Benjamins Publishing Company. https://doi.org/10.1075/btl.22

Fu, G. M., \& Zheng, S. (Eds.). (2002). Collected Works of Ling Shuhua (p. 214). Beijing: Culture and Arts Press.

Hermans, T. (2004). Translation in Systems: Descriptive and System-oriented Approaches Explained (p. 119). Shanghai: Shanghai Foreign Language Education Press.

Isaacs, R. H. (1958). Scratches on Our Minds: American Views of China and India (p. 86). New York: John Day Co..

Kong, Q. D. (2007). Kong Qingdong's Comment on Lu Xun's Short Stories (p. 193). Shenyang: Liaoning People's Publishing House.

Lao She. (1982). Selections from Laoshe (pp. 342-348). Chengdu, Sichuan People's Publishing House.

Lefevere, A. (1992b). Translation, Rewriting, and the Manipulation of Literary Fame. London and New York: Routledge.

Lefevere, A. (Ed.). (1992a). Translation, History, Culture: A Source Book (p. 149). London and New York: Routledge. https://doi.org/10.4324/9780203417607

Li, S., \& Zhu, J. P. (2018). Framing Strategies in Chi-Chen Wang's Translation of Ah $Q$ and Others. Chinese Translators Journal, 2, 84.

Liu, D. X. (Ed.). (1999). Master Work of YangZhensheng (pp. 18-41). Beijing: Huaxia Publishing House.

Lu Xun. (2013). Call to Arms (pp. 32-34). Nanjing: Yilin Press.

Shu, Y. (Ed.). (1999). The Masterwork of Lao Xiang (p. 99). Beijing: Huaxia Publishing House.

Toury, G. (2001). Descriptive Translation Studies and Beyond (p. 56). Shanghai: Shanghai Foreign Language.

Venuti, L. (2009). Strategies of Translation. In Mona Baker (Ed.), Routledge Encyclopedia of Translation Studies (p. 240). Shanghai: Shanghai Foreign Language Education Press.

Wang, C.-C. (1934). Western Tides in Chinese Literature. Pacific Affairs, 7(2), 127-138. https://doi.org/10.2307/2751112

Wang, C.-C. (1946). Traditional Literature: Nature and Limitations. In MacNair and H. Farnsworth (Eds.), China 
(pp. 386-396). Los Angeles: University of California.

Wang, C.-C. (Ed.). (1947). Stories of China at war (pp. v-132). New York: Columbia University Press.

Wang, C.-C. (Trans.). (1941). Ah $Q$ and others: selected stories of Lusin (pp.67-72). New York: Columbia University Press.

Wang, C.-C. (Trans.). (1944). Contemporary Chinese Stories (pp. vii-190). New York: Columbia University Press.

Wu, B. (2006). On the Translator's Subjectivities (pp. 128-129). Beijing: Foreign Languages Press.

Yang, J. D. (2018). A Comparative Study of the Culture-specific Items in Five English Translations of Lu Xun's The New Year Sacrifice. Shanghai Journal of Translators, 2, 63-68.

Zhang, H. S. (1991). Lao She's Short Stories and the Family Culture of Beijing. Journal of Zhenzhou University, 6, 86-92.

\section{Copyrights}

Copyright for this article is retained by the author, with first publication rights granted to the journal.

This is an open-access article distributed under the terms and conditions of the Creative Commons Attribution license (http://creativecommons.org/licenses/by/4.0/). 